\title{
Lean Production Applications in a Manufacturing Company
}

\author{
Ali Görener ${ }^{a^{*}}$, Hümeyra Başer ${ }^{b}$, Ali Türkyllmaz ${ }^{c}$ \\ ${ }^{a}$ Department of International Logistics, Istanbul Commerce University, 34672, Istanbul, Turkey \\ ${ }^{b}$ Graduate School of Sciences, Fatih University, 34500, Istanbul, Turkey \\ ${ }^{c}$ Department of Industrial Engineering, Fatih University, 34500, Istanbul, Turkey
}

\begin{abstract}
Lean production is a production model which comes about the pursuit of companies to be able to meet competition and make effective production. The main purpose of lean production is to get control about the wastage. This study includes the requirements for the success of the lean production and how the lean production system can be established. In this paper, lean production techniques were applied to the electric water heater line. Measurements using lean initiatives were made, operation cycle times were determined, and Kaizen improvement methods and line balancing methods were applied according to the results. And the last section of study showed conclusion of lean implementation.
\end{abstract}

Keywords: Lean production; Waste; Kaizen; System

\section{(C) 2013 Published by SSBFNET}

\section{Introduction}

In today's competitive environment, firms in the market place to maintain and grow must produce wide variety of products depending on customer demand that delivered in the shortest time, excellent quality and low price. Production activities are focused on the customer, must be fast and good quality. In addition, if firms can make an efficent production they will provide competitive advantage as well as cost savings and investment.

Lean production reveals all the disruptions and problems within the current existing system. Then to better for the future, lean production includes following the path of continuous improvement and never stops chasing the perfection of production techniques, management principles and lean thinking. The other businesses implementing lean production, the required amount of production can be perfect and without waste, at the designated time. Therefore, enterprises should be adopted as a model for efficient production of lean manufacturing.

In the literature; Bamber and Dale (2000) conducted a research study into the application of lean production methods to a traditional aerospace manufacturing organization. Similarly, this approach is applied by Green, Lee and Kozman (2010) to implement lean manufacturing in a material handling system of a petroleum drill bit manufacturing company, by Waldhausen et al. (2010) to improve clinic efficiency. Staats, Brunner and Upton (2011) examined the applicability of lean production to knowledge work by investigating the implementation of a lean system at an Indian software services firm. Demeter and Matyusz (2011) concentrated on how companies could improve their inventory turnover performance through the use of lean applications. Recently, lean methodology is used by Chen, Chen and Huang (2013) to improve the efficiency and effectiveness of supply chain management. Furthermore, Karim and Zaman (2013) tried to develop an effective methodology for implementing lean production strategies.

In this study, the definition of lean manufacturing systems, principles, ideas and techniques used is discussed, selected a process in a company producing household appliances and situations encountered during the transition to lean production in the classic production, switching stages and according to the current situation with the transition from the gains in the lean is shown.

\footnotetext{
* Corresponding author: Ali Görener, Tel.: +90 21655394 22. E-mail address: agorener@ticaret.edu.tr
} 


\section{Lean Production}

Lean production is an integrated set of activities designed to achieve production using minimal inventories of raw materials, work-in-process, and finished goods. Parts arrive at the next workstation "just in time" and are completed and move through the process quickly. Lean philosophy is also based on the logic that nothing will be produced until it is needed (Jacobs and Chase, 2008).

The main objective of lean opinion starts with first raw material of value. The material of value then aims to reach the final customer quickly by continuous streaming, during the proccess the product becomes more valueable. To make this a success we need to look at the value chain from an integral framework to dispose of waste. And we need to direct all activities with the aim of creating the best value for customer.

As an implementing the lean production Toyota is the first and the best. The basis of this approach appeared in Taiichi Ohno's trip to America with executives, who is underlying system of Toyota. Their purposes were to improve production systems which could compete against American companies. At that time, there was mass production system which is still used at the present day developed by Henry Ford in America. This system makes production in crowds according to appraisement. After produce it was bottom to quality control. System has been adopted by Taiichi Ohno. At the result of this review, Eiji Toyota the youngest and the most successfull engineer of Toyota motor company and Taiichi Ohno decided that the mass production system which was applied by Ford was not approppriate for Japan. Instead of this, they have begun to work on "Toyota Production System (TPS)" as called.

TPS can be regarded as one of the most popular production concept (Black, 2007). Its ground-breaking approach to implement a lean production philosophy on the shop-floor of companies has revolutionised the approach of manufacturing (Thun, Drüke and Grübner, 2010). If we will express the TPS's success with the quantify; an employee was working 2150 hours per a year in Toyota, but in the United States, an employee was working 1920 hours per a year in the years of 1980s. An employee was producing 16 automobiles per a year in Chrysler which was one of the leading firms in America in 1982, but in Toyota an employee was producing 56 automobiles. In 1987, an installation of a car was taking 31 hours in General Motors, but in Toyota an automobile installation was doing every 16 hours. The most important success is the time of changing the mold was reductioned to the incredible level of time. This time was reduced from 8 hours to 3 minutes (Ohno, 1996).

In the lean production, every step of production was taken according to the next step, when they needed and how quantities. The cards as called as Kanban. By applying this logic in the chain of other suppliers, we created a system which was producing according to demand, minimized of stocks and so that, we could use reosources much more effective. One of the key features of Toyota Production System was the respecting the people. Safety and security of employees, smoothness of job envoirenment, cleanliness, to make the workers to work according to standarts and ergonomics are the obtrusive elements. Everything is done to make the workers to do their jobs complete and to take part in development activities (Liker J., 2004). To have sustainable competitive environment we need to improve especially quality, cost and the shipment. The main aims of lean thinking is to make efficiency and productivity analysis of excellent process quits the wastes so then it reduce the cost and offers a perfect values to the customer.

The lean production has five main pillars (Womack and Jones, 2007):

Value: It is a facility or product which meet the customer's requests in a particular instant and place with a particular price. To produce the product/service before needed time is as waste as to produce wrong products/service.

Value Stream: The Lean Production looks at the system as a whole. The essential of lean is to eliminate the operations which are not creat a value on system.

Continuous Streaming: It is to produce from a product request quantity and time instead of producing one prodcut much. It means to consider to take customer's offers when shaping the product.

Pull: It means that the production will not start without customer's request. The product is produces when requested.

Excellence: There could be continuous restorates on products produced each time, just because of the system is not stocking. In this way it is possible to eliminate the wastes and repair the mistakes before products accumulated.

Eliminate waste means to do not add value to the customer service or product directly to minimize all activities. The sources of stocks are all kinds of waste. In this context, at every stage of production, inventories (raw materials, 
intermediate products, goods stocks) and the coarseness of the most basic elements of wastes hould be reduced (Karlsoon and Ahlstrom, 1996).

Here are the basic objectives of the JIT (Browne, Harjen and Shivnan, 1998):

- Zero fault

- Zero inventory

- Zero preparation time

- Zero time to ensure

- Zero carriage

\section{An Application of Lean Production in Ihlas Domestic Appliances Company}

In this part of the paper, we will present an example of application of lean production that has been discussed in the previous parts, in Ihlas Domestic Appliances Company. We will discuss, respectively, process methodology of the application, problems in the application that needs to be straighten, solutions introduced to overcome these problems, and benefits to be gained with the overcoming of the problems. Established in 1975 and started to production, Ihlas Domestic Appliances Production Industry and Trade Incorporated Company (IHEVA) presented its small appliances, which takes human health as a priority and facilitates the domestic life from the very beginning, to the consumers. Situated with its energetic coaching staff in Beylikduzu Organised Industrial Zone (BOSB) in a closed area of 21175 $\mathrm{m}^{2}$ which employs 300 personnel composed of 220 assembly staff and 80 administrative staff, the Company contunies its production in Cleaning Robots Factory, Water Heaters and RO Water Prufiers Factory, Carpet Washing Machine Factory and Plastical Injection Printing Plant.

To start the application by picking a department which is a bottleneck in the factory and has plenty of inventory will be the first criteria to choose the place. Later, it will be better to choose a place, where we can better observe benefits of the new system and get better results, and to start the application with this place. This is because, we want to give a good reason both to the administrative staff and the workers to accept the new system. Due to all these reasons, we accept that the application will be on the production line of electrical water heaters. In this study we use time survey forms. Accordingly, we determined the standard working time by measuring 3 circular times for each production process of the study.

\subsection{Defining Problem}

There are 31 workers in the production line of the electrical water heaters. The working hours for them are from 08:05 to 18:25. In the factory, parts produced by the Company and the pieces such as cables screws coming from the subsidiary industry is combined together and packed after quality control and served to the market. All the works under the production process is labor intensive. In the workplace, there are three control machines and U-shape assembly line on that the production is made. Currently, the total area of the workplace is $100 \mathrm{~m}^{2}$. The $25.6 \mathrm{~m}^{2}$ part of this area is for the assembly line and the remaining $74.4 \mathrm{~m}^{2}$ part is for workers and buffer stocks.

We have determined the following problems after we have determined the order of the material and observed the assembly process.

Ergonomics: Workers are working under ergonomically unfavorable conditions. The sitting workers works from $90^{\circ}$ angle to the assembly line. For this reason, they are often faced with different diseases. Hernia is among the most frequent diseases. Problems related to ergonomics leds to work loss, as well. This is because due to these problems work efficieny decreases and inefficiency becomes the trend.

Worker Inefficiency: There are abeyance periods for the workers. This springs from unequal distributions to the operators. While some workers get behind their schedule others are early to finish.

Balance of The Line is Not Ideal: The unequal distribution of works to operators brings about an imbalanced line. For this reason, workers become inefficient and products become less qualified.

Stream of Work and Materials is Not Orderly: In the production area walking roads are long and transportation is a lot. Not being on time to replace runout materials causes suspentions and breaks the work stream. For this reason, while production stock accumulates there remains the assembly line flowing in chain. 
Buffer Stocks: Because of mass production (there is no one piece flow). Desultory impediments in production timing create lots of semi-finished buffer stocks. These buffer stocks not only block workers' work space and time but also elongate walking paths for material flow. The transportation of materials used in a workplace from the warehouse by a vehicle. In the production line of water heater, materials are demanded as mass orders instead of this vehicle. This makes it hard to control the stocks and creates an unnecessary material stock.

The Placement of Materials is Not Orderly: The place of the hand utensils used in the assembly process is not ergonomically designed. Because the operator does not align assembly utensils orderly it causes the production process to prolong and increases the work burden for itself.

\subsection{Production Time for the Water Heaters and Problem Formulation}

The production of a water heater occurs in 31 steps and each step is taken by a different operator. These operations are:

1. Tank control and nut fastening

2. Attaching the oring and resistor to the tank

3. Flange screwing

4. Flange screwing

5. Assembly of reset thermostat

6 . Flange screwing

7. Back door assembly

8. Clemens screwing

9. Aperture grouping

10. Aperture body assembly

11. Cable assembly

12. Switch screwing

13. Cable assembly to the resistor

14. Attaching clamp and socket

15. Thermostat screwing

16. Limit thermostat assembly

17. Key screwing
18. Checking before closing the front box

19. Partial checking

20. Mosten control

21. Hand-eye control

22. Closing the front box

23. Attaching the screw and tag to the front box

24. Attaching the button and the stage tag

25. Attaching the barcode and front front panel tag

26. Packaging and putting in the operating manual

27. Putting the product into the box

28. Separator and assembly

29. Closing the box, sticking the barcode and warning label

30. Product installation and sticking the barcode onto the box

31. Packaging

In time survey forms, there are different turn times for each operation. This means that working time for each operator is different. Deducing from these data, it is obvious that under the existing circumstance capacity-use rate and waiting times are imbalanced. One part of conducted time measurements take place in Appendix 1.

We can define the current situation and existing problems in the production line of electrical water heaters as follows:

The Company determines the number of water to be produced on a monthly base. The number is between maximum 31000 and minimum 9000 water heaters. The line of electrical water heater produces according to the demand. Generally, it produces on alternate days and workers produce different products when not producing water heaters. This is the first and the most important problem. For this reason, sometimes producing on time becomes a problem. While sometimes there is overproduction leading the excess to product to wait, in other days there is overtime because the product does not match up. In addition, another important thing to mention is that the Company is not able to have production breaks in order to decrease its financial expenses and make the maintenance for the assembly line.

\subsection{The method to be Applied in Order to Regulate the Problematic Area}

The first method to be applied to regulate the problematic area is the establishment of a lean team. Transition from a years-long production process to a new one will be difficult for both managers and workers. After the transition to a new project, in order to show the determination of lean production and get efficient results it is necessary to include a department which will both do the works to be done in the transition process and do the monitoring job after the transition is complete. 
Generally, the most salient thing to the in forming a lean team is to choose engineers for the engineering department in line with lean production techniques that the whole staff adopts and the existing production process. In the lean team formed for this application, in addition to product and quality control engineers, journeymen working in the production line of the electrical water heaters. The team to be in the application process of lean production is composed of one advisor, one group spokesman, one vice group spokesman and seven members, adding up to ten in total. The first step after forming the team is to give an education of the application of lean production. Workers need to refrain from extravagancies and act in a lean thinking in each process of their work. This consciousness in lean production comes with educations that encourages each worker to adopt lean working style rather than with with a pressure coming from above in a hierarchical order. Lean education is given to all the workers, both to blue and white collars in the Company.

We have identified the following objectives in order to eliminate the problems that are currently existing after the forming the lean team and the giving the necessary education.

Objectives:

1. To increase the efficiency by $25 \%$.

2. To gain a $30 \%$ profit in the assembly lounge by decreasing the surplus stock in the workarea and bringing the materials in time through a system of vehicles in the warehouse.

3. To increase the efficiency $20 \%$ by regulating orderly arranging the positions of the workers and the places of the materials. To make and supply the necessary equipments to achieve this.

4. To decrease the working time by $30 \%$ by determining the takt time and decrease the waiting time.

5. To redetermine the number of the workers by balancing the work load and flow.

6. To redetermine the number and working hour of the controlling machines.

7. Preperation for the transition to Kanban in order to regulate the transportation system in the warehouse and production departments

\subsection{The First Application of Kaizen}

The first application that we have made is a 5 days kaizen group activity. The aim is to create a continuous stream cell in a week. The lean team members that we have previously selected firstly learned the principles of continuous stream and then replanned the necessary changes by going to the production area in order to evaluate the real conditions there. Later they tested the production by placing the necessary machine, material and operator.

\subsubsection{Assembly Line Balancing}

Balancing the assembly line is the most important problem to be solved by mass production companies. The main aim in balancing work to design assembly lines is to maximize the utilization of existing resources. In line with this aim, work items are distributed among the stations by assigning the station times equal or very close.

By assembly line balancing, works are categorized and stations are established accordingly. Operation times of these stations are made close to each other. And under these circumstances assembly line is made to work without a hitch. Hence, the maximum benefit is achieved.

In the firm, on this application one of the line balancing study explained below example:

Firstly, 5th., 6th., $7^{\text {th }}$., and 8th. operators, who works on the water heaterline, are considered. Each operator's works are called seperately a, b, c, d, e, etc.

5th. operator completes his works at total 15 second time and each work respectively is $5 \mathrm{a}(2 \mathrm{sec}),. 5 \mathrm{~b}(3 \mathrm{sec}),. 5 \mathrm{c}(4 \mathrm{sec}$.$) ,$ $5 \mathrm{~d}(4 \mathrm{sec}),. 5 \mathrm{e}(2 \mathrm{sec}$.$) .$

6th. operator completes his works at total 14 second time and each work respectively is $6 \mathrm{a}(1 \mathrm{sec}),. 6 \mathrm{~b}(12 \mathrm{sec}$.$) ,$ $6 \mathrm{c}(1 \mathrm{sec}$.$) .$ 
7th. operator completes his works at total 14 second time and each work respectively is which are $7 \mathrm{a}(1 \mathrm{sec}),. 7 \mathrm{~b}(2 \mathrm{sec}$.), $7 \mathrm{c}(3 \mathrm{sec}),. 7 \mathrm{~d}(7 \mathrm{sec}),. 7 \mathrm{e}(1 \mathrm{sec}$.$) .$

8th. operator completes his works at total 12 second time and each work respectively is $8 \mathrm{a}(1 \mathrm{sec}),. 8 \mathrm{~b}(3 \mathrm{sec}),. 8 \mathrm{c}(6 \mathrm{sec}$.$) ,$ $8 \mathrm{~d}(2 \mathrm{sec}$.$) .$

Takt time is $20.8 \mathrm{sec}$. in current state. In this case the whole operations cycle times remain under the takt time. Now, we should share some operations between operators to re-create a workflow. The main goal of that to closing the operation cycle times, upward to takt time. Every operation in the water heater does not require much skill. Thus, each operator can do all the work. So, we start sharing in the operator's work backwards. Leaving the 8th operator to off-line is the first goal. For that, operation $8 \mathrm{c}(6 \mathrm{sec}$.) and $8 \mathrm{~d}(2 \mathrm{sec}$.) are added to 7 th operator. So, 7 th operators cycle time is completed $22 \mathrm{sec}$. time. Then, operation $5 \mathrm{c}(4 \mathrm{sec}$.) and $5 \mathrm{~d}(4 \mathrm{sec}$.) are added to 6 th operator and now his total cycle time is $22 \mathrm{sec}$. After, $8 \mathrm{a}$ and $8 \mathrm{~d}$ operations are added to 10 th operator. At the same time, $5 \mathrm{a}$ and $5 \mathrm{~b}$ operations are added to operator 4 . So on 8th and 5th operators would be off-line.

All operations are not sharing only the both of 6th and 7th operators according to the explanations above. As a result of those things, it is shown that the line balancing may not be exactly made. But if the rest of the line balancing process would be searced, we just observe the full balanced line.

\subsubsection{Other Improvement Activities for the Lean Production System}

Takt time is determined: The time obtained by dividing the available production time to the consumer demand is called takt time. Takt is a German word used to define an exact time period just like a musical measure. The aim of takt time is to achieve an exact overlap of production and demand.

As a result of the lean work that we have done, it is determined that the average of montly production is 33000 and montly work day is 22 . This means that the average number of daily production is 1500 .

The average of daily working time of the factory is 33600 seconds. Out of this time, 2400 is spared for tea breaks and the remaining 31200 seconds is pure working time. The daily demand of the product by consumers is 1500 . So, the takt time is $31200 / 1500=20.8$ seconds. In other words, customer demands a product in each 20.8 seconds.

Job-step sequence is determined: The distribution of a particular work to a single worker in a constant sequence and the adaptation of this to the takt time is called job-step sequence.

In this part, the working time of the operators is determined and cycle times for each operator are recalculated. The deviations in workers' work are determined. In these calculations, it was observed that the cycle time of operations is below the takt. For this reason, with drawing the work sequence and and time towards the takt time by the method of balancing the assembly line, the work division among the operators is rearranged.

You can find in the below graph an analysis of takt time and cycle time of the operations. Figure 1 shows analysis of takt time and cycle time of the operations.

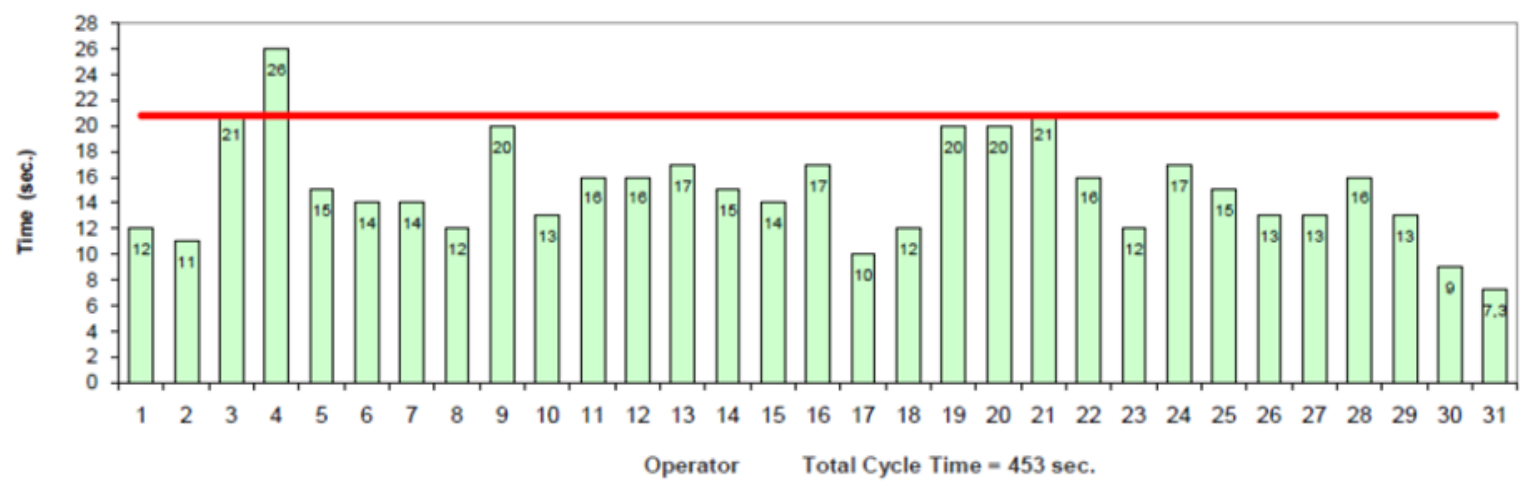

Figure 1. Production Cycle Time Before Kaizen 
Standards are set and optimization is complete: Initially, it is necessary to apply JIT principles in a lean style. We should minimise the waiting times that cause some loss and decrease the cycle times of the workers as much as possible. At the same time, it is necessary to have a labour force that can easily adapt different works and responsibility and is multidimensional. As a result, taking all these points into consideration, the production line is divides in three parts as A, B and C. Part A deals with assembly work; Part B deals with control work; and Part C deals with packaging work. This division is done just on paper in order to arrange the placement of the operator and regulate the works easily. In reality, the line is united.

Part A, 18 operators work at first. With the new work distribution and newly calculated cycle times, the number of operators decreases to 12 and 6 operators are left idle. As a result, we have obtained a $(6 / 18) \times 100=33.3 \%$ efficiency from this part.

$\mathrm{B}$ is the control part. This is the automatic operation region. There are 2 controlling machine working in each 30 seconds and two operators leading them. The working time of the machine is standardized; it does not depend on the operator. The duty of the machine is to checks whether the water heater leaks water or not. In the same area, there is a high-voltage control machine which checks whether there is any electricity leakage in a water heater. This machine is also led by an operator and an operation takes 13 seconds here. In the first application, we have not made any changes in this region but we aimed to decrease the usage time of the machine. 3 operators continue to work.

In Part C, 12 operators work. With new regulations an work distribution, 8 people continue to work while 4 people remain idle. The increase in effectiveness in this region is $(4 / 12) \times 100=\% 30$.

Table 1. Efficiency Situation

\begin{tabular}{lcc}
\hline & Operator Number & $\begin{array}{c}\text { Per Capita Production } \\
\text { (Number/Day) }\end{array}$ \\
\hline Before Kaizen & 31 & 48.4 \\
\hline After the First Application of Kaizen & 23 & 65.2 \\
\hline Variation & 8 & 16.8 \\
\hline
\end{tabular}

An ergonomical work environment is created: Because the operators work while seated, their body is under more pressure and burden. For this reason, if they take an adverse movement the injury risk is quite. Operators' working desks are placed in a $90^{\circ}$ angle towards the production line and the materials are placed on it randomly. This work desks takes a lot of unnecessary space and creates a difficulty for the operator to reach the line. For this reason, working area and working style of the operators are rearranged and as in any other places kaizen improvements are made in this area too. The working environment of the operators is redesigned according to main principles of ergonomy. In these regulations desks are situated in parallel to the line and remade according to the height of the operator. As a result, it is prevented for worker to take adverse movements, to stretch and to turn. By rearranging the placement of materials and hand utensils of the worker in line with their usage, either with left or right hand, the decrease in performance and bodily stress is prevented. Moreover, the height of the production line is taken to the standard level.

Kanban system is established: As a result of the new improvements, it is observed that there are some problems in the production because the system of vehicles is weak and there is waiting times for the finished materials of the operators to be supplied. To prevent this, we have established the kanban system. We have determined the materials used one by one.

Spiderman is determined: Spiderman is a name given to the person who checks the production environment and transports the necessary materials to the operator in a lean production. This concept is not among the standardized lean concepts. All the materials, used to prevent unnecesaary material stock and create the necessary environment for operator to work conveniently, exist equally in the production area in parallel with their sizes and usage frequency. For example, there are 100 water heaters' heads ready near the line before the production starts. Spiderman has to transport material stock in each 100 products by following the product number from the scorboard in the production area. This transportation work maybe a hourly duty. For example, there is a 6-hours stock for the screws used in the assembly process. Spiderman has to work according to the hour again and in each 6-hours he has to check the 
production area an supply necessary materials. All the finished and nearly-finished materials in the production area has to be under the responsibility of the spiderman. The operator must not do any other work that does not bring value. He must never go and bring the finished materials and make the production wait for this.

Production Cycle Time After The First Application of Kaizen

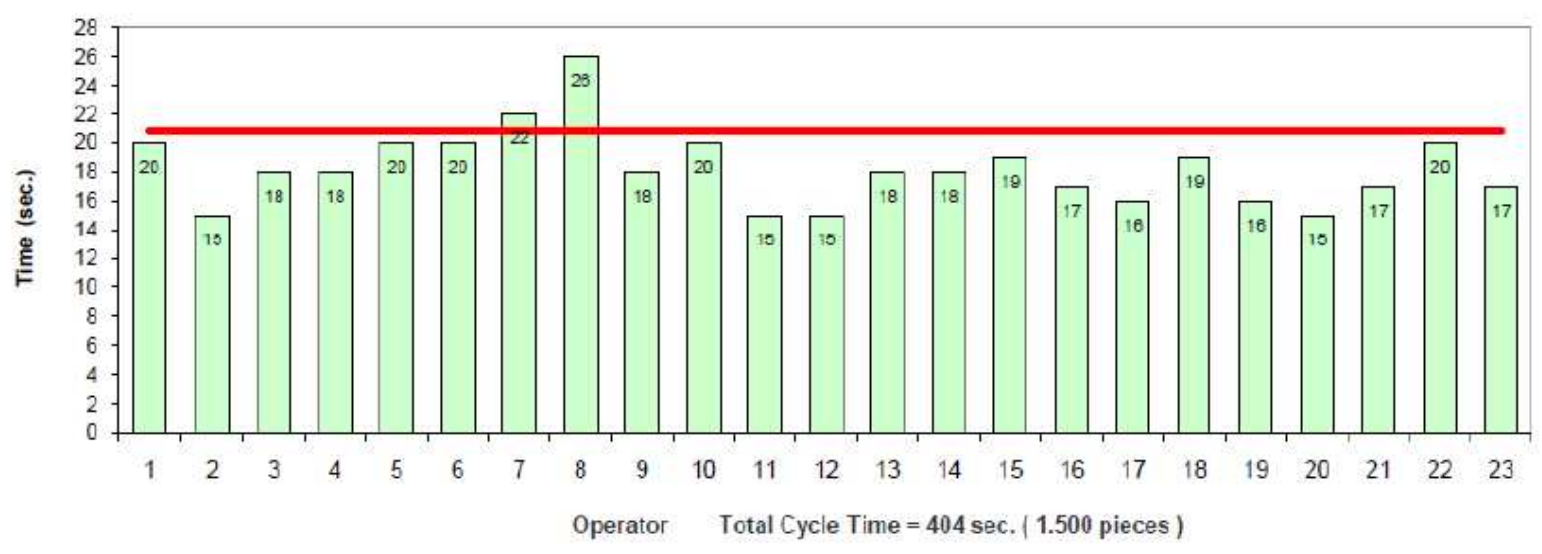

Figure 2. Production Cycle Time After the First Application of Kaizen

The car for transportation of materials is made: Hand cars are designed to carry materials from the stock in order to supply kanban boxes.

\subsection{The Second Application of Kaizen}

The aims are achieved as a result of the first application of kaizen. The application of first kaizen has lasted 5 days. During this process, operators have tried to become accustomed to the new order. At the end of 5 following days, operators have become accustomed to the distribution of new tasks and production field, and they have increased the tempo even more.

In this application, firstly units of production were considered. In order to make improvements in production, there is a stock of finished products for immediate demands. To reduce or if possible to destruct stockpiles of finished product without disturbing the smoothness of production, new targets were determined.

Objectives:

1. To increased the efficiency by $30 \%$,

2. To gain a $30 \%$ profit by decreasing the stocks in the work area,

3. To achive a space saving of $20 \%$,

4. To decrease the production time by $30 \%$ by determining the takt time and decreasing the waiting time,

5. To redetermine the number of workers by balancing the work load and flow.

In line with the above-mentioned objectives, firstly, we have standardized the monthly prodution demand to 22000 and monthly working day to 22 . Hence, the average of daily production becomes 1000 . In terms of working time and labour force, the factory is able to produce at this amount. Under the circumstances of production delay, this problem will be handled by overwork. The pure working time remained 30600 seconds. As a result, the new takt time became $30600 / 100=30.6$ seconds.

With this new takt time, work distribution and operator numbers are redetermined as in the previous application. The existing operator number is decreased to 15 from 23. Because 15 people started to work on the production line, instead of 31 people, we have saved up from the line, too. The initial $25.6 \mathrm{~m}^{2}$ line decreased to $22.19 \mathrm{~m}^{2}$. The remaing part 
was $34.9 \mathrm{~m}^{2}$ after the first application, now it became $21.51 \mathrm{~m}^{2}$. Table 2 and 3 show the results obtained after the applications.

Table 2. The Efficiency in the Line for the Water Heaters.

\begin{tabular}{llll}
\hline & Operator Number & Daily Production & $\begin{array}{l}\text { Per Capita Production } \\
\text { (Number/Day) }\end{array}$ \\
\hline Before Kaizen & 31 & 1500 & 48.4 \\
\hline $\begin{array}{l}\text { After the First } \\
\text { Application of Kaizen }\end{array}$ & 23 & 1500 & 65.2 \\
\hline $\begin{array}{l}\text { After the Second } \\
\text { Application of Kaizen }\end{array}$ & 15 & 1000 & 66.7 \\
\hline Efficiency Increase: $38 \%$ & & & \\
\hline
\end{tabular}

Table 3. The Pure Usage in the Line for Water Heaters.

\begin{tabular}{llll}
\hline & Line $\left(\mathrm{m}^{2}\right)$ & Other $\left(\mathrm{m}^{2}\right)$ & Total $\left(\mathrm{m}^{2}\right)$ \\
\hline Before Kaizen & $25.6 \mathrm{~m}^{2}$ & $74.4 \mathrm{~m}^{2}$ & $100 \mathrm{~m}^{2}$ \\
\hline $\begin{array}{l}\text { After the First } \\
\text { Application of Kaizen }\end{array}$ & $25.6 \mathrm{~m}^{2}$ & $34.9 \mathrm{~m}^{2}$ & $60.5 \mathrm{~m}^{2}$ \\
\hline $\begin{array}{l}\text { After the Second } \\
\text { Application of Kaizen }\end{array}$ & $22.2 \mathrm{~m}^{2}$ & $21.5 \mathrm{~m}^{2}$ & $43.7 \mathrm{~m}^{2}$ \\
\hline Pure amount of space saved: $\mathbf{5 6 \%}$ & & \\
\hline
\end{tabular}

\subsection{Challenges in the Application}

During the application of the improvement methods, we have faced with dramatic reactions form the workers. Workers accustomed to work while seated could not adopt the idea to work while standing. They reacted dramatically against both to the lean team leading the application and to the gangers. In order to stop these reactions, brochurs explaining the ergonomical working principles are posted around. A series of seminars are given by expert doctors to raise workers' awareness.

Another problem faced during the application is frequent worker absence. The operators can take a day off by presenting an excuse or due to health problems. However, the assembly line production system balanced according to the number of operators. In order to prevent these problems in this application, we spare two more workers to work in the production line. Because the production line of electrical water heaters is not a complex production line, almost every worker can do every work on it. For this reason, the substitute two workers are educated to handle every operation. They can be used in the case of the absence of any operator. When there is operator absence, these two workers help other operators in case if any defect or other problems in the production process.

\subsection{Financial Improvements as a Result of the Application}

Below you can find the benefits gained as a result of the improvement work done in Ihlas Home Appliances Company by using the philosopy and methods of the lean production, work study and kaizen improvement methods.

If we take the monthly production capacity of the Company as 1500 water heaters, monthy labour cost as 1800 TL and monthly working time as 22 days, the profit the Company gain after an annual work will be as followes:

The daily cost of a worker: $(1800 \mathrm{TL}) /(22$ day $)=82 \mathrm{TL} /$ day

Before kaizen applications:

Monthly cost of workers: (31) x (82 TL): $2542 \mathrm{TL}$

Monthly labour cost: $(2542 \mathrm{TL}) /(1500$ piece $)=1.6 \mathrm{TL} /$ day 
After kaizen applications:

Monthly cost of workers: (15) x (82 TL): $1230 \mathrm{TL}$

Monthly labour cost: $(1230 \mathrm{TL}) /(1000$ piece $)=1.2 \mathrm{TL} /$ day

Gains:

Difference: $1.6-1.2=0.4 \mathrm{TL} /$ day

Daily gains: (0.4 TL/day) x 1000 piece/day = $400 \mathrm{TL} /$ day

Annual gains: (400 TL/day) x 250 day/year $=100000 \mathrm{TL} /$ year

After these improvements the company will gain 100000 TL only from the labour cost. In addition to this, there are many gains not included into the calculations. As a result of improvement in space and technical materials, lots of gains are achieved.

We can examine the gains from space under two headings, as gains in construction and management. The Company saves up from space and utilized this idle space in the production of another goods. Instead of establish in another factory in a different place, the Company utilized this idle space to produce a different product. This is the main gain in construction. In addition, the Company saves up from other costs like lightening, heathing, cleaning, and etc. In the process of improvements, there was a necessity for new working desks, kanban boxes, and cars for transporting the materials. Because the Company is able to produce all these, there was not additional costs for these materials.

\section{Conclusion}

In this study, Company producing home appliances, we have utilized some of lean production tools and analyzed the techniques of Kaizen continuous improvement. We have observed the extravagancies by the methods of time measurement. We have determined the deficiencies in the work flow, placement of material and production planning.

During the improvement process, we saved up both from production and from operators' material usage. Before the first application, there were 31 operators producing 1500 water heaters daily. Per capita production was 48.4. After the application, we have achieved the production of 1500 water heaters by 23 operators in a day. Per capita daily production was 65.2. After the second improvement, we replanned the production process. Now the daily production was 1000 water heaters by 15 operators. Per capita daily production is 66.7 . The increase in water heater line is $38 \%$. As a result of improvements, the total space, used in line with the location of operators and production flow, decreased from $100 \mathrm{~m}^{2}$ to $60.5 \mathrm{~m}^{2}$. The gain from space after the first application of Kaizen is $34.9 \%$. After the second application of Kaizen, the size of the line decreased form $25.6 \mathrm{~m}^{2}$ to $22.19 \mathrm{~m}^{2}$; and the remaining part decreased form $34.9 \mathrm{~m}^{2}$ to $21.5 \mathrm{~m}^{2}$. So, the total area used becomes $43.7 \mathrm{~m}^{2}$. After the all improvements, the total gain from space is $56 \%$.

Lean production is not just a production method, but philosophy of lean thinking. Although the Company that we have made our application is a small factory, the lean production and lean management will bring big gains if applied properly.

\section{References}

Bamber, L. \& Dale, B. G. (2000). Lean production: a study of application in a traditional manufacturing environment, Production Planning \& Control, 11 (3), 291- 298.

Başer, H. (2011). Lean manufacturing, value stream mapping: A case study in a production company, Graduate Institute of Sciences Thesis-Fatih University, Turkey.

Black, J. T. (2007). Design rules for implementing the Toyota Production System. International Journal of Production Research, 45 (16), 3639-3664.

Browne, J., Harjen, J. \& Shivnan, J. (1998). Production Management Systems: A CIM Perspective. Addison Wesley Publishing.

Chen, J. C., Cheng, C. H. \& Huang, P. T. B. (2013). Supply chain management with lean production and RFID 
application: A case study, Expert Systems with Applications, 40, 3389-3397.

Demeter, K. \& Matyusz, Z. (2011). The impact of lean practices on inventory turnover. International Journal of Production Economics, 133, 154-163.

Green, J. C., Lee, J \& Kozman, T. A. (2010). Managing lean manufacturing in material handling operations. International Journal of Production Research, 48 (10), 2975-2993.

Jacobs, F. R. \& Chase, R. B. (2008). Operations and Supply Management: The Core. The McGraw-Hill Companies.

Karim, A. \& Zaman, K. A. U. (2013). A methodology for effective implementation of lean strategies and its performance evaluation in manufacturing organizations, Business Process Management Journal, 19 (1), $169-196$.

Karlsoon, C. \& Ahlstrom, P. (1996). Assesing changes towards lean production. International Journal of Operations \& Production Management, 16 (2), 24-41.

Liker, K. J. (2004). Toyota Tarzı 14 Yönetim İlkesi. (Çeviren: U. Şensoy.) Optimist Yayınları.

Ohno, T. (1996). Toyota Ruhu- Toyota Üretim Sisteminin Doğuşu ve Evrimi. (Çeviren: C. Feyyat ), Scala Yayıncılık.

Womack, J. \& Jones, D. (2007). Bütünü Görmek. (Çeviren: A. Okur, U. Kulac, \& B. Kılınç), Yalın Enstitü Derneği.

Staats, B. R., Brunner, D. J. \& Upton, D. M. (2011). Lean principles, learning, and knowledge work: Evidence from a software services provider, Journal of Operations Management, 29, 376-390.

Thun, J. T., Drüke, M. \& Grübner, A. (2010). Empowering Kanban through TPS-principles - an empirical analysis of the Toyota Production System. International Journal of Production Research, 48 (23), 7089-7106.

Waldhausen, J. H. T., Avansino, J. R., Libby, A., Sawin, R. S. (2010). Application of lean methods improves surgical clinic experience, Journal of Pediatric Surgery , 45, 1420-1425. 
Appendix 1

Time Survey Form for Operation 1

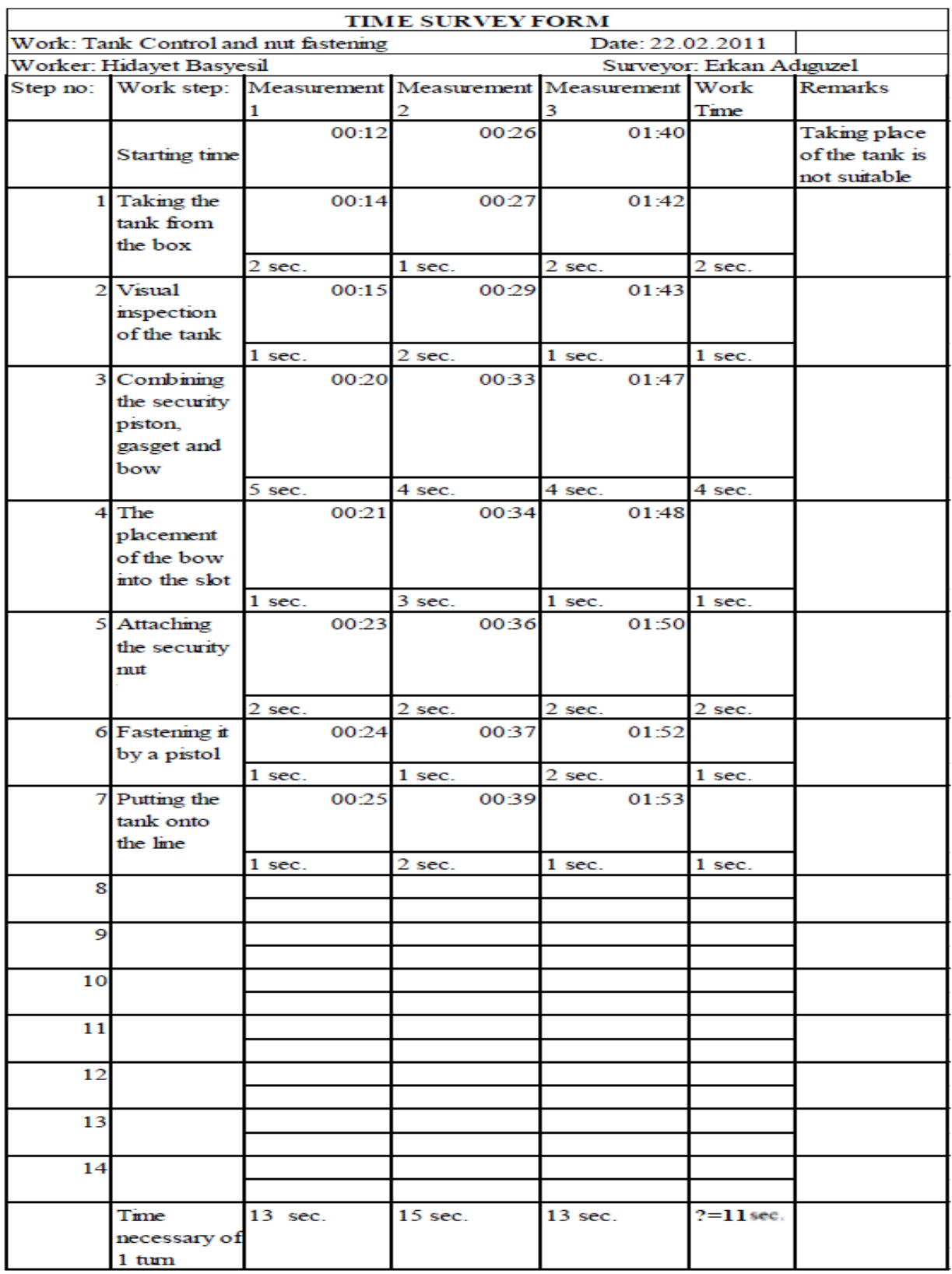

